\title{
TRADISI ULUR-ULUR DITINJAU DARI PENDEKATAN KONSTRUKSTIVISME SEBAGAI UPAYA PENGUATAN PENDIDIKAN NILAI DALAM PEMBELAJARAN IPS
}

\author{
Danan Tricahyono ${ }^{1}$, Sariyatun ${ }^{2}$ \\ ${ }^{1,2}$ Magister Pendidikan Sejarah, Pascasarjana, Universitas Sebelas Maret \\ danancahyono2@gmail.com \\ sarifkipuns@yahoo.co.id
}

Received: 02 Oktober 2020; Revised: 21 November 2020; Accepted: 28 Desember 2020 DOI: http://dx.doi.org/10.37905/aksara.7.1.79-88.2021

\begin{abstract}
Abstrak
Globalisasi membawa pengaruh negatif yang berdampak pada pergeseran orientasi nilai kehidupan maka diperlukan kearifan lokal sebagai sarana proteksi. Kearifan lokal memiliki kandungan nilai-nilai positif yang dapat diwariskan kepeda generasi saat ini sebagai pegangan hidup. Tujuan penelitian ini memberikan alternatif pembelajaran IPS dengan pendekatan konstruktivisme sebagai upaya untuk penguatan pendidikan nilai. Metode penelitian yang digunakan melalui studi pustaka. Artikel ini akan memaparkan sejarah tradisi ulur-ulur, prosesi upacara ulur-ulur dan alternatif gagasan konseptual model konstruktivisme McClintock dan Black yang terdiri atas tujuh tahapan yaitu observasi, konstruksi interpretasi, kontekstualisasi, belajar keahlian kognitif, kolaborasi, interpretasi jamak, dan manifestasi jamak.

Kata kunci: ulur-ulur, konstruktvisme, IPS, pendidikan nilai

Abstract

Globalization has a negative influence that has an impact on shifting the orientation of the value of life, so local wisdom is needed as a means of protection. Local wisdom contains positive values that can be passed on to the current generation as a way of life. The purpose of this study is to provide an alternative to social studies learning with a constructivist approach as an effort to strengthen value education. The research method used is through a literature study. This article will describe the history of the ulur-ulur tradition, the procession of ulur-ulur, and alternative conceptual ideas of the McClintock and Black constructivism model which consists of seven stages, namely observation, interpretation construction, contextualization, learning cognitive skills, collaboration, multiple interpretations, and multiple manifestations.
\end{abstract}

Keyword: ulur-ulur, constructivism, social studies, value education

\section{PENDAHULUAN}

Bangsa Indonesia dikenal sebagai negara yang memiliki keanekaragaman suku, agama dan ras. Indonesia memiliki suku sekitar 1300 (Akhsan \& Syaputra, 2011). Masing-masing suku me ${ }^{1}$ miliki adat istiadat yang berbeda. Sebut saja suku Jawa yang mendiami wilayah Pulau Jawa bagian timur dan tengah, masyarakatnya sudah sangat

\footnotetext{
${ }^{1}$ and Black constructivism model which
} 
beragam. Salah satunya adalah suku Jawa yang mendiami Kabupaten Tulungagung yang terletak di Provinsi Jawa Timur. Masyarakat Tulungagung masih banyak yang memegang teguh tradisi warisan nenek moyang. Salah satunya adalah tradisi ulur-ulur. Tradisi tersebut dipegang teguh oleh masyarakat Tulungagung khususnya yang berada di Desa Sawo, Gedangan, Gamping, dan Ngentrong di Kecamatan Campurdarat.

Tradisi ulur-ulur dilaksanakan sebagai rasa syukur terhadap karunia Tuhan Yang Maha Esa yang telah memberikan limpahan rezeki berupa sumber mata air Telaga Buret yang tidak pernah kering. Ketersediaan sumber mata air tersebut digunakan oleh para warga yang berada di empat desa tadi sebagai sarana untuk mengairi sawah khususnya di musim kemarau. Tradisi ulur-ulur sebagai kearifan lokal merupakan bagian dari sebuah kebudayaan. Fungsi dari kebudayaan diantaranya sebagai pedoman hidup yang diwujudkan dalam bentuk hukum, norma, dan nilai. Keberadaan hukum, norma dan nilai sebagai kontrol atau tata tertib di masyarakat. Hal inilah yang mendasari sebuah tradisi selalu diturunkan dari generasi ke genarasi (Kistanto, 2017).

Nilai-nilai yang termuat dalam sebuah kearifan lokal tradisi ulur-ulur menjadi bahan yang menarik bagi guru-guru untuk dikemas dalam pembelajaran IPS. Mengingat orientasi dari pendidikan IPS adalah mengembangkan sikap sosial peserta didik sebagai aktor sosial yang dapat mengambil peran di masyarakat (Birsyada, 2016). Maka pendidikan nilai menjadi penting untuk diinternalisasikan pada diri peserta didik. Secara secerhana pendidikan nilai dapat diartikan sebagai proses penanaman sekaligus penguatan nilai baik agama, budaya, etika, dan estetika menuju pembentukan pribadi peserta didik yang memiliki karakter serta keterampilan yang diperlukan dirinya, masyarakat, dan negara (Tricahyono, Sariyatun, \& Ediyono, 2020). Dengan demikian pendidikan nilai sudah semestinya menjadi landasan pembelajaran.

Fenomena sejak awal 2000 an sampai sekarang arus globalisasi begitu deras masuk ke Indonesia dengan membawa dampak positif dan negatif. Dampak negatif inilah yang perlu diantisipasi karena mengakibatkan perubahan sosial yang negatif pula. Perubahan sosial yang terasa adalah disorientasi nilai-nilai kehidupan yang dipegang oleh para generasi muda. Kecenderungannya para generasi muda mengikuti tren kekinian yang menjadikan mereka semakin liberal. Sebagai contohnya menjamurnya budaya tiktok. Jika dicermati ini tidak sesuai dengan kepribadian bangsa yang menjunjung adat ketimuran. Apabila fenomena ini dibiarkan dikhawatirkan membuat identitas atau jati diri bangsa akan luntur. Maka disinalah fungsi kearifan lokal sebagai sarana proteksi terhadap pengaruh negatif globalisasi menjadi sebuah keharusan (Suwardani, 2015). Penelitian dari Ramdani (2018) menyebutkan bahwa kearifan lokal penting sebagai pembangunan karakter bangsa karena di dalamnya terdapat seperangkat nilai-nilai positif yang dapat dijadikan laku kehidupan. Pengemasanya dapat dilakukan dengan model pembelajaran kontekstual. Penelitian dari Asriati (2012) juga menyebutkan bahwa kearifan lokal yang berisi gagasan-gagasan setempat yang bersifat bijaksana, bernilai baik yang tertanam dan diikuti warga dapat dijadikan pendidikan karakter melalui pembiasaan di sekolah. Berangkat dari beberapa penelitian terdahulu penulis akan memberikan kebaruan dalam pembelajaran IPS dengan mengemas materi tradisi ulur-ulur melalui pendekatan konstruktivisme.

Konstruktivisme yang menitikberatkan interaksi antar individu serta interaksi dengan kultural history sebagai kunci dari perkembangan manusia (Vygotski, 1986). Hubungan antar individu, interaksi dengan orang-orang di lingkungan sekitar akan 
menstimulasi proses-proses perkembangan dan mendorong pertumbuhan kognitif. Aspek kultural histori memberikan penekankan jika pembelajaran dan pengembangan tidak bisa dipisahkan dari konteksnya. Interaksi peserta didik dengan guru, lingkungan masyarakat mampu mengubah cara berpikir peserta didik. Dengan demikian kemampuan guru menghadirkan pembelajaran kontruktivisme yang dikaitkan dengan materi kearifan lokal seperti tradisi ulur-ulur akan memberikan kontribusi positif bagi peserta didik untuk menghayati makna yang terkandung dalam tradisi tersebut (Fithri, 2014). Berdasarkan paparan tersebut penulis akan mengajak pembaca untuk mengetahui upaya penguatan pendidikan nilai melalui pembelajaran konstruktivisme dengan materi tradisi ulur-ulur.

\section{METODE}

Penulisan artikel ini menggunakan metode studi kepustakaan dengan melakukan analisis terhadap karya tertulis seperti buku dan artikel hasil penelitian. Penulis melakukan analisis dan sintesis terhadap muatan materi pada sumber yang dijadikan referensi kemudian direfleksikan dalam bentuk tulisan seperti berikut (Agung, 1992).

\section{HASIL DAN PEMBAHASAN}

\section{Sejarah Tradisi Ulur-Ulur}

Tradisi ulur-ulur merupakan upacara tradisional yang digelar sebagai bentuk rasa syukur terhadap ketersediaan sumber air yang terus mengalir. Menurut perkembangannya tradisi ulur-ulur digelar secara turun-temurun oleh warga dari empat desa yang berada di Kecamatan Campurdarat yaitu Desa Sawo, Desa Gedangan, Desa Ngentrong, dan Desa Gamping. Tradisi ulur-ulur dilaksanakan di Telaga Buret. Telaga ini memiliki diameter 75 meter yang dilingkari oleh hutan lebat. Secara lokasi Telaga Buret berada di sebelah timur Dusun Buret, Desa Sawo. Nama ulur-ulur digunakan untuk mempopulerkan upacara yang dilaksanakan di Telaga Buret. Nama ulur-ulur memiliki makna "nggowo ulu wektune bumi, yang intinya keberadaan mata air yang terus mengairi tanaman warga dari ke empat desa tersebut. Jadi nama tersebut sesuai dengan asal-usul Telaga Buret (Ardiani, 2018).

Keberadaan tradisi ulur-ulur memiliki kaitan erat dengan Eyang Djigangdjaya yang memiliki garis hubungan dengan Kerajaan Majapahit. Tokoh tersebut dikenal sebagai pemrakarsa atas terciptanya Telaga Buret. Terbentuknya Telaga Buret dilatarbelakangi oleh beberapa masalah yang muncul di lingkungan Kecamatan Campurdarat. Mulai dari masalah kemarau panjang, adanya wabah yang mematikan dan musibah besar. Melalui usaha Eyang Djigangdjaya yang mengadakan upacara sradda (pepetri dan sesaji) yang di dalamnya berisi ruwatan dan tayuban sebagai upaya memanggil tokoh Dewi Sri dan Ki Joko Sedono yang telah pergi dari desa. Usaha tersebut menuai hasil dalam bentuk air langsung memancar dari tanah secara terus menerus sampai membentuk telaga (Pertiwi, 2019).

Saat Telaga Buret telah terbentuk, Eyang Djigangdjaya meninggalkan daerah tersebut dengan meninggalakan pesan kepada para warga sekitar. Adapun pesan tersebut berupa adanya larangan bagi para warga untuk memakai ikat kepala yang sama dengan yang dipakai Mbah Djigangdjaya, tidak diperkenanakan untuk menunggang kuda Pancal Panggung seperti yang dimilikinya, dan tidak diperbolehkan kepada siapapun untuk mengambil dan membunuh segala jenis kehidupan yang berada di sekitar Telaga Buret. Pelbagai pesan tersebut selalu diwariskan dari generasi ke generasi karena yang 
melanggar akan mendapatkan musibah. Hal ini sebagai pondasi dasar berupa adanya penghargaan kepada alam untuk terus menjaga keseimbangan ekosistem serta menjadikan tradisi ulur-ulur terus dilestarikan (Pertiwi, 2019).

Ditinjau dari segi proses pelaksanaan upacaranya, tradisi ulur-ulur mengalami perubahan dari waktu ke waktu. Pada awal diadakan sampai tahun 2006 upacara ulur-ulur dilaksanakan oleh keempat desa secara bergantian. Mulai 2006 sampai saat ini upacara ulur-ulur dilaksanakan secara bersama-bersama oleh para warga dari ke empat desa tersebut. Dari sisi keterlibatan para peserta dalam pelaksanaan tradisi ulur-ulur pernah mengalami pasang surut. Pada 1973 di Desa Sawo berkembang ajaran Islam garis keras. Ideologi tersebut mempengaruhi kepala desa Sawo saat itu. Maka kepala desa sebagai pemangku kebijakan mengeluarkan aturan kepada para warganya untuk tidak melaksanakan tradisi ulur-ulur yang menurutnya menyimpang dari ajaran Islam (Ardiani, 2018). Dampaknya pun terasa ketika tradisi ulur-ulur tidak dijalankan yaitu adanya musibah melanda Desa Sawo. Pada saat itu muncul musibah angin puting beliung dari pusaran air telaga yang melumat habis balai desa Sawo. Seiring pergantian kepala desa tradisi ulur-ulur tetap dilaksanakan sampai hari ini.

\section{Prosesi Upacara Ulur-Ulur}

Upacara ulur-ulur digelar satu tahun sekali tepatnya di bulan Sela pada kalender penanggalan Jawa. Untuk hari yang dipilih tepat di hari Jumat Legi (Ardiani, 2018). Secara tata cara pelaksanaan upacara ulur-ulur terbagi menjadi tiga. Pertama, prosesi persiapan keberangkatan. Kedua, prosesi upacara. Ketiga, berkenaan dengan pengaturan sesaji (Puthut, 2018). Segala persiapan upacara dilaksanakan di rumah kepala kesa Sawo mengingat dari segi lokasi dekat dengan Telaga Buret. Dari rumah kepala desa Sawo rombongan dibagi menjadi beberapa tim dengan tugas masing-masing. Pertama, tim pembawa jodang (keranjang segi empat berisi makanan dan sesaji), kedua, tokoh yang berperan menjadi pengantin dengan membawa pakaian penganten panjaga telaga yang diiringi oleh beberapa warga yang berpakaian adat jawa.

Masih bertempat di telaga tepatnya di ujung dekat telaga terdapat meja putih dimana di atasnya terdapat dua patung kecil sekitar 35x20 cm sebagai perwujudan Dewi Sri dan Ki Joko Sedono. Di tempat utama terdapat altar pemujaan yang di atasnya terdapat segala media pemujaan seperti kembang setaman (bunga setaman), bunga boreh dan dupa beserta pendukungnya. Prosesi upacara dimulai dengan para iring-iringan berangkat dari rumah kepala desa Sawo. Adapun susunan iring-iringan terbagi menjadi beberapa baris. Barisan paling depan diisi oleh pembawa jodang dengan cara dipikul dua orang yang satu di depan dan satunya di belakang. Jumlah jodang yang dipikul ada empat buah, jumlah tersebut merepresentasikan jumlah desa yang berpartisipasi pada upacara ulur-ulur. Barisan kedua berisi pasukan pembawa obor dan bokor (di dalamnya ada dupa yang telah dinyalakan). Barisan ketiga diisi sepasang penganten yang membawa peralatan pakaian manten dan diiringi oleh gadis cantik yang membawa bokor beriris bunga aneka warna untuk ditaburkan ke telaga. Barisan keempat berisi para sesepuh desa dan para pemimpin upacara. Peserta semuanya berjalan dengan khidmat sehingga suasana terasa sakral.

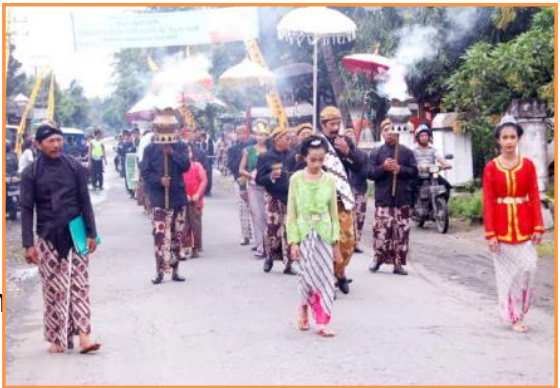




\section{Gambar 1. Iring-Iringan Peserta}

Setibanya di lokasi para pembawa jodang meletakan yang telah dibawa di tempat sesaji. Makanan tradisional disiapkan di samping tempat sesaji. Sementara yang bertugas pembawa pakaian penganten langsung menuju tempat manten yang berupa Dewi Sri dan Joko Sedono. Rangkaian inti acara berisi tiga orang yang berperan memimpin di sesaji. Mereka membacakan doa dan adanya prosesi memandikan penganten menggunakan air yang berisi bunga setaman dan bunga boreh serta menaburkan di tepi telaga. Setelah prosesi doa selesai makanan diberikan ke peserta yang hadir dan sebagaian diberikan kepada hewan yang berada di telaga.

\section{Tradisi Ulur-Ulur Sebagai Penguatan Pendidikan Nilai}

Fungsi dari pendidikan nilai adalah pembentukan karakter bagi peserta didik. Pembelajaran yang berorientasi pada sikap sudah semestinya menjadi fokus utama bagi para pendidik. Mengingat visi dan misi pemerintah yang utama berupa pembentukan karakter. Hal ini telah termuat dalam Rencana Pembangunan Jangka Panjang Nasional 2005-2025 (Cahyono, 2013). RPJM tersebut termuat dalam Undang-Undang Republik Indonesia Nomor 17 tahun 2007 yang menjelaskan secara rinci bahwa terwujudnya karakter bangsa yang tangguh, kompetitif, berakhlaq mulia dan bermoral berdasarkan Pancasila yang dicirikan dengan watak dan perilaku manusia dan masyarakat Indonesia yang beragam, beriman dan bertaqwa kepada Tuhan Yang Maha Esa, berbudi luhur, bertoleran, bergotong royong, berjiwa patriotik, berkembang dinamis, dan berorientasi pada ipteks.

Orientasi dari pendidikan IPS sebagaimana yang termuat dalam silabus menjadikan peserta didik dapat memahami lingkungan dan masyarakat secara lokal, nasional dan global, menyadari keragaman budaya, mengembangkan keterampilan sosial dan menguasai perkembangan teknologi. Maka materi pembelajaran dengan bersumber dari kearifan lokal dapat menjadi sebuah alternatif. Kearifan lokal seperti tradisi ulur-ulur mengajarkan banyak nilai-nilai kehidupan. Melalui pendekatan konstruktivisme, guru dapat menjadi mediator untuk membuat model pembelajaran yang menarik. Penulis mencoba memberikan alternatif dari salah satu aliran pendekatan konstruktivisme menekankan adanya pembelajaran bermakna (meaningfull). Pembelajaran bermakna merupakan proses mengaitkan informasi baru dengan konsep yang relevan yang terdapat pada kognitif peserta didik. Struktur kognitif di dalamnya berisi fakta, konsep dan generalisasi-generalisasi yang telah dipelajari oleh peserta didik (Rahmah, 2013).

Belajar bermakna banyak dipengaruhi struktur kognitif yang ada, stabilitas dan kejelasan pengetahuan dalam suatu bidang studi tertentu dan pada waktu tertentu. Pembelajaran bermakna terjadi apabila seseorang belajar dengan mengasosiasikan fenomena baru ke dalam struktur pengetahuan mereka (Daryanto \& Karim, 2017). Keberadaan materi ulur-ulur yang dikemas sebagai materi pengayaan akan sejalan dengan prinsip pembelajaran IPS dan pembelajaran bermaknanya. Agar pembelajaran IPS lebih menarik perlu adanya kontekstualisasi materi dengan cara guru mengambil topik-topik 
Volume $: 07$
Nomor $: 01$
Bulan : Januari
Tahun : 2021
http://ejurnal.pps.ung.ac.id/index.php/AKSARA/index

yang berada di lingkungan sekitar mulai dari sekolah, lokal, regional dan peristiwa global. Kontekstualisasi pembelajaran akan menumbuhkembangkan kepedulian peserta didik terhadap lingkungan dan salah satunya mengenal budaya lokal mereka.

Muatan pendidikan nilai yang terdapat dalam tradisi ulur-ulur diantaranya syukur, jati diri, solidaritas atau gotong royong (Puthut, 2018). Kemampuan guru untuk menghadirkan tradisi ulur-ulur sebagai materi pengayaan dan mengemasnya secara benar akan berdampak terhadap perubahan sikap dari peserta didik. Kemauan guru untuk tidak melihat tradisi ulur-ulur secara biasa melainkan membukakan makna di balik prosesi ulur-ulur dapat mempengaruhi struktur kognitif peserta didik. Dalam pembelajaran bermakna terjadi proses peserta didik akan mengkonstruksi apa yang telah ia pelajari dan mengasosiasikan pengalaman, fenomena, dan fakta-fakta baru ke dalam struktur pengetahuan mereka (Rahmah, 2013).

Nilai syukur, jati diri dan solidaritas atau gotong royong bisa menjadi modal sekaligus penguat bagi para peserta didik untuk diterapkan dalam kehidupan di luar sekolah. Penulis mencoba mengelaborasi terkait ketiga muatan pendidikan nilai tersebut dalam menghadapi tantangan kehidupan saat ini. Pertama nilai syukur, sikap ini penting dimiliki oleh peserta didik sebagai pengingat diri untuk terus mensyukuri apa yang telah diterimanya, untuk saat ini mereka berstatus sebagai peserta didik maka sikap syukur yang harus dimiliki adalah rasa berterima kasih karena telah mendapatkan ilmu pengetahuan serta dapat menempuh pendidikan di sekolah dengan aman dan nyaman.

Kedua tentang jati diri, keberadaan tradisi ulur merupakan identitas lokal masyarakat empat desa di kecamatan Campurdarat yang di dalamnya penuh dengan nilainilai kemanusiaan. Di tengah derasnya arus globalisasi keberadaan jati diri atau identitas menjadi penting. Globalisasi yang menawarkan cara hidup liberal memiliki dampak negatif berupa adanya dekadensi moral (Suryono, 2008). Melalui tradisi ulur-ulur dapat direfleksikan nilai-nilai positifnya. Misalnya tentang nilai kemanusiaan. Jadi secara hakikat nilai kemanusian bukan menyoal hubungan manusia dengan manusia melainkan lebih dari itu. Dalam konteks ini manusia dengan alam sekitar. Guru dapat menjelaskan pentingnya menjaga kelestarian alam agar tumbuh-tumbuhan dan hewan dapat hidup dengan baik sehingga keseimbangan alam tetap terjaga. Semua ini sejalan dengan prinsip ulur-ulur dimana salah satu tujuannya untuk melestarikan ekosistem di Telaga Buret.

Ketiga tentang gotong royong, nilai tersebut sejalan dengan solidaritas yang di dasari oleh rasa peduli. Tradisi ulur-ulur secara jelas mengajarkan nilai-nilai tersebut. Sebagaimana dapat dilihat dari proses persiapan sampai prosesi acara diantara para warga saling bahu membahu menyukseskan acara. Fenomena sekarang rasa kepedulian diantara generasi muda (peserta didik) mulai memudar. Faktornya dapat disebabkan oleh adanya pemanfaatan smarhphone dimana menimbulkan efek ketergantungan. Para generasi muda enggan untuk jauh smarhphone sehingga minim untuk berinteraksi dengan orangorang di sekitarnya. Berangkat dari kondisi inilah guru bisa menguatkan nilai-nilai solidaritas melalui refleksi tradisi ulur-ulur.

Melalui pertimbangan bahwa pembelajaran IPS harus mampu mencetak generasi cerdas sosial maka perlu dikembangkan model pembelajaran yang mengarahkan kepada peserta didik untuk berani mengambil peran sosial di masyarakat (Birsyada, 2016). Maka penulis memberikan alternatif model konstruktivisme McClintock dan Black yang terdiri atas tujuh tahapan (Supardan, 2016). Pertama, fase observasi: Para peserta didik diberikan instruksi untuk melakukan kegiatan observasi terutama atas sumber-sumber, 
materi-materi, foto, gambar, rekaman video, dan tentang kebudayaan daerah. Sebagai contohnya para peserta didik diberikan kesempatan untuk menyimak video dari youtube seputar tradisi-ulu-ulur. Maka pada kegiatan awal tersebut guru dapat memberikan stimulus berupa pertanyaan. Misalnya coba cermati proses rangkaian tradisi ulur-ulur dan temukan nilai-nilai positif kehidupan apa yang ada di sana?

Kedua, konstruksi interpretasi, peserta didik diberikan kesempatan untuk menginterpretasikan pengamatan agar siap untuk memberikan penjelasan dengan mengacu pada kerangka pertanyaan yang telah dimiliki pada tahap observasi. Ketiga, kontekstualisasi dimana peserta didik membangun konteks untuk penjelasan mereka, guru mengarahkan kepada para peserta didik untuk mengaitkan hasil pengamatan dari video dengan realitas di sekitar mereka. Para peserta didik dapat mengaitkan keberadaan tradisi ulur-ulur dengan tradisi pernikahan. Mengingat tradisi pernikahan sering digelar di sekitar kehidupan peserta didik. Diantara kedua tradisi tersebut terdapat kesamaan konsep tentang nilai gotong royong. Keempat, belajar keahlian kognitif, guru menjadi fasilitator untuk membantu pengamatan, penguasaan peserta didik, interpretasi, dan kontekstualisasi.

Kelima, kolaborasi, guru dapat mendesain pembelajaran berbasis kelompok kecil. Setiap kelompok terdiri dari empat sampai lima orang. Para peserta didik bekerja sama dalam observasi, menafsirkan, dan kontekstualisasi. Sehingga dari tahap ini akan ditemukan kebaruan-kebaruan ide dari masing-masing individu yang akan terangkum dalam ide besar kelompok. Keenam, interpretasi jamak, para peserta didik memperoleh fleksibilitas kognitif dengan memiliki kemampuan menunjukkan berbagai penafsiran dari berbagai perspektif. Ketujuh, manifestasi jamak, peserta didik memperoleh transferabilitas dengan melihat berbagai penjelmaan penafsiran yang beragam. Sehingga dari sini akan ditemukan berbagai macam pengetahuan baru terkait nilai-nilai kehidupan dari tradisi ulur-ulur. Melalui zone proximal development dimana jarak antara arena level perkembangan aktual dan level perkembangan potensial semakin mudah ditingkatkan melalui interaksi dengan teman sebaya, maupun interaksi dengan teman diluar teman sebaya yang lebih dewasa sebagai usaha peningkatan kompetensi kognisi, afeksi dan konasi.

\section{Kesimpulan}

Salah satu tujuan dari pembelajaran IPS menjadikan peserta didik insan yang cerdas sosial. Kemampuan guru menghadirkan pembelajaran berbasis kearifan lokal tradisi ulur-ulur yang dieksplor dengan pendekatan konstruktivisme menjadikan pembelajaran lebih bermakna dimana peserta didik akan berpikir kritis dan kreatif dalam memperoleh informasi, dapat bijaksana dalam memahami informasi sehingga akan meningkatkan dimensi kepribadiannya yakni berupa sikap dan motivasi. Saat peserta didik mencapai tahap ini guru tinggal memberikan refleksi sekaligus penguatan akan nilai-nilai positif yang diwariskan oleh tradisi ulur-ulur sehingga menjadikan peserta didik sebagai aktor sosial yang cerdas dan luaranya dapat menjadi insan-insan yang mampu ikut berkontribusi untuk menyelesaikan masalah sosial di sekitarnya.

\section{Daftar Rujukan}

Agung, I. G. (1992). Metode Penelitian Sosial (Pengertian dan Pemakaian Praktis). 
Jakarta: Gramedia Pustaka Utama.

Akhsan, N., \& Syaputra, H. (2011). Kewarganegaraan, Suku Bangsa, Agama, Dan Bahasa Sehari-Hari Penduduk Indonesia. Jakarta: Baadan Pusat Statistik.

Ardiani, S. M. (2018). Ulur-Ulur Sebagai Ritual Syukur. Retrieved September 28, 2020, from http://blog.iain-tulungagung.ac.id/pkij/2018/07/17/memaknai-ulur-ulursebagai-ritual- syukur/

Asriati, N. (2012). Mengembangkan Karakter Peserta Didik Berbasis Kearifan Lokal Melalui Pembelajaran di Sekolah. Jurnal Pedidikan Sosiologi Dan Humaniora, 3(2), 106-119.

Birsyada, M. I. (2016). Dasar-Dasar Pendidikan IPS (Suatu Pendekatan Teoritis dan Praktis). Yogyakarta: Ombak.

Cahyono, A. S. (2013). Otonomi Daerah Dalam Rangka Membangun Karakter Pemimpin Bangsa Berbasis Budaya Lokal Untuk Mempertahankan Keutuhan NKRI. Jurnal Universitas Tulungagung Bonorowo, 0(1), 72-87.

Daryanto, \& Karim, S. (2017). Pembelajaran Abad 21. Yogyakarta: Gava Media.

Fithri, R. (2014). Buku Perkuliahan: Psikologi Belajar. Surabaya: Prodi Psikologi, Fakultas Dakwah dan Ilmu Komunikasi, UIN Sunan Ampel.

Kistanto, N. H. (2017). Tentang Konsep Kebudayaan. Sabda: Jurnal Kajian Kebudayaan, 10(2), 1-11. https://doi.org/10.14710/sabda.v10i2.13248

Pertiwi, L. C. (2019). Bersyukur Melalui Tradisi Ulur-Ulur di Telaga Buret. Retrieved September 28, 2020, from https://etnis.id/bersyukur-melalui-tradisi-ulur-ulur-ditelaga-buret.

Puthut, I. W. (2018). Studi Pelaksanaan Upacara Ulur-Ulur Desa Sawo Kecamatan Campurdarat Kabupaten Tahun 2018. Universitas Nusantara PGRI Kediri.

Rahmah, N. (2013). Belajar Bermakna Ausubel. Al-Khwarizmi: Jurnal Pendidikan Matematika Dan Ilmu Pengetahuan Alam, 1(1), 43-48. https://doi.org/10.24256/jpmipa.v1i1.54

Ramdani, E. (2018). "Pendidikan karakter merupakan tanggung jawab bersama. S. Jupiis: Jurnal Pendidikan Ilmu-Ilmu Sosial, 10(1), 1.

Supardan, D. (2016). Teori dan Praktik Pendekatan Konstruktivisme dalam Pembelajaran. Edunomic, 4(1), 1-12.

Suryono, H. (2008). Konfigurasi Identitas Nasional, Nasionalisme Dalam Era Globalisasi 


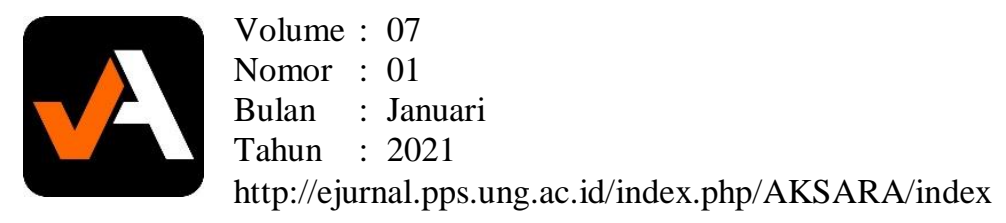

Suatu Harapan dan Tantangan. MIIPS, 7(2 Sptember 2008), 157-163.

Suwardani, N. (2015). Pewarisan Nilai-nilai Kearifan Lokal untuk Memproteksi Masyarakat Bali dari Dampak Negatif Globalisasi. Jurnal Kajian Bali (Journal of Bali Studies), 5(2), 247-264.

Tricahyono, D., Sariyatun, \& Ediyono, S. (2020). Analisis Wacana Kritis Pendidikan Multikultural dan Pendidikan Nilai Dalam Buku Teks Sejarah SMA. Jurnal Ilmu Ilmu Sosial, 17(1), 1-10. https://doi.org/https://doi.org/10.21831/socia.v17i1.32294

Vygotski, L. (1986). Thought and Language. In Behavioural Neurology (Vol. 5). https://doi.org/10.3233/BEN-1992-5106. 
Volume : 07

Nomor : 01

Bulan : Januari

Tahun : 2021

http://ejurnal.pps.ung.ac.id/index.php/AKSARA/index

88 AKSARA: Jurnal IImu Pendidikan Nonformal 